\title{
Enrichment of poultry manure with biomass ash to produce organomineral fertiliser
}

\author{
Omer Hulusi Dede ${ }^{\dagger}$, Hasan Ozer \\ Department of Environmental Engineering, Engineering Faculty, Sakarya University, Sakarya 54187, Turkey
}

\begin{abstract}
In this study, the contribution of hot biomass ash to enrichment of the mineral content and to reducing the moisture content of broiler poultry manure was investigated. For this purpose, the mixtures have been prepared by adding biomass ash at varying rates $(10 \%, 20 \%$, $30 \%, 40 \%$ and $50 \%)$ and at different temperatures $\left(100^{\circ} \mathrm{C}, 150^{\circ} \mathrm{C}, 200^{\circ} \mathrm{C}\right.$ and $\left.250^{\circ} \mathrm{C}\right)$ according to the dry matter content $(74.77 \%)$ of the poultry manure. The results showed that incorporation of biomass ash into poultry manure at $50 \%$ at $250^{\circ} \mathrm{C}$ reduced the moisture content from $25.23 \%$ to $9.82 \%$. Regarding the maximum $\mathrm{N}$ in the final product, the ideal temperature of biomass ash has been obtained at $150^{\circ} \mathrm{C}$. The highest nutrient contents were obtained at 50\% biomass ash incorporation. The highest dose of biomass ash application had significantly increased nutrients, such as Ca $(19.34 \%), \mathrm{K}(4.03 \%), \mathrm{Fe}(1,545 \mathrm{mg} / \mathrm{kg}), \mathrm{Mn}(812 \mathrm{mg} / \mathrm{kg})$ and $\mathrm{Zn}(479 \mathrm{mg} / \mathrm{kg})$ in the final organomineral fertiliser formulation. Overall, it was concluded that the addition of hot biomass ash can dramatically decrease the moisture content of poultry manure and therefore provide odour and pathogen removal and increase its plant nutrient content.
\end{abstract}

Keywords: Ammonia volatilisation, Enrichment, Fertilising value, Plant nutrition, Poultry litter

\section{Introduction}

The rapid rise in global population has triggered an exponential increase in the demand for foods and agricultural products. In order to meet the rising demand, it has been aimed to elevate agricultural production and a corresponding increment has been detected in the use of chemical fertilisers to supply nutrients essential for boosting the production ratios [1]. However, in a myriad of studies conducted lately, it has been reported that using chemical fertilisers is unsustainable, in addition to its environmental hazards, because of problems such as the extremely fast increase of soil $\mathrm{pH}$ in the long term. Lately, a fall has been measured in the efficiency of chemical fertiliser use $[2,3]$. The most common argument in a number of relevant studies is that organomineral fertilisers are the best alternatives to chemical fertilisers by virtue of their nutrient potential and positive effects on the improvement of soil characteristics [4]. Organomineral fertilisers are formed by adding minerals to organic wastes that exhibit manure values and soil-improving effects; hence, they are classified as a distinctive manure group different from organic and mineral manures based on their inherent char-

This is an Open Access article distributed under the terms of the Creative Commons Attribution Non-Commercial License (http://creativecommons.org/licenses/by-nc/3.0/) which permits unrestricted non-commercial use, distribution, and reproduction in any medium, provided the original work is properly cited.

Copyright (C) 2018 Korean Society of Environmental Engineers acteristics [5].

One of the most effective sources to be utilised in the composition of organomineral fertiliser is poultry manure, due to its high nitrogen $(\mathrm{N})$ content [6]. Nonetheless, one third of the total nitrogen in the content of poultry manure is ammonium $\left(\mathrm{NH}_{4}-\mathrm{N}\right)$. In manure stored raw and composted in the open areas, ammonium changes into a volatile form, ammonia $\left(\mathrm{NH}_{3}\right)$, as an effect of factors such as ventilation, moisture content and temperature [7-9]. This can, as a consequence of the decrease in the nitrogen content of manure, lead to a decline in the nutrient value of a plant [10]. Additionally, nitrogen content that leaves the manure after direct application of raw manure to agricultural lands creates pollution. Pollution is a direct threat for the natural environment, particularly for surface and underground water sources [11-12]. To conserve nitrogen in the manure, it is imperative to immediately dry the waste from the poultry house to prevent the waste from turning into microbial nitrogen. Furthermore, an additional benefit of the drying process is decreasing the pathogens and antibiotic residuals inside poultry manure [13]. In current applications, the drying process is divided into two groups: fast drying via primary energy sources and slow solar drying via solar

Received March 1, 2018 Accepted April 23, 2018

${ }^{\dagger}$ Corresponding author

Email: ohdede@sakarya.edu.tr

Tel: +90-264-2955761 Fax: +90-264-3460633

ORCID: 0000-0001-8574-820X 
sources. That being said, high temperatures $\left(>250^{\circ} \mathrm{C}\right)$ in the fast drying process and long periods in the slow drying process can limit the primary objective, which is nitrogen conservation [14-15].

Besides, power plants operated by burning plant-based raw materials are increasingly on the rise now. In this energy production process, significant amounts of waste heat and hightemperature ash (biomass ash) are created by plant nutrients [16-17]. This ash that needs to be cooled is a valuable resource for fast drying of poultry house wastes and enriching the mineral content [18]. In this study, we aim to utilise resources by preparing varied ratios of poultry manure and biomass ash mixtures and the usability of these mixtures as organomineral fertiliser as well as identify the optimum temperature for the mixing of biomass ash to minimise nitrogen loss and its contribution to enriching the mineral content of manure.

\section{Materials and Methods}

Fresh poultry manure used in this study was obtained from a poultry farm in the Sakarya Province of Turkey. Immediately after the transfer of fowl to the slaughterhouse, sample manure was collected from different places in the poultry house to reach a total of $10 \mathrm{~kg}$ and homogeneously mixed and, after quickly reaching the laboratory, the sample was stored in $4^{\circ} \mathrm{C}$ until the date of analysis. Biomass bottom ash to mix with poultry manure was collected from the burner unit of a prototype power plant of an energy company in Bursa, Turkey where agricultural plants and forest wastes were used as fuel. The prototype plant (Fig. 1) utilised a fluid boiler-burner unit. In the applied process, dried agricultural plants and forest wastes were fed to the boiler and burned at a temperature of $800^{\circ} \mathrm{C}$. Hot ash (biomass bottom ash) forged after the burning process was periodically exhausted from the system. In this system, a negligible amount of fly ash was also formed. However, since this study aims to utilise the most crucial waste of the system, bottom ash, fly ash was not used. The particle dimension distribution of the biomass ash was as follows: $100-200 \mu \mathrm{m}=5 \%, 50-100 \mu \mathrm{m}=26 \%, 2-50$ $\mu \mathrm{m}=75 \%$ and $<2 \mu \mathrm{m}=4 \%$.

In the process of mixing poultry manure and biomass ash, dry matter amounts of manure were ignored. Biomass ash, in varied ratios of weight that differed according to dry matter ratio $(74.77 \%)$ and temperatures, was added to $1,000 \mathrm{~g}$ of manure. For all the analyses conducted within the scope of this study,

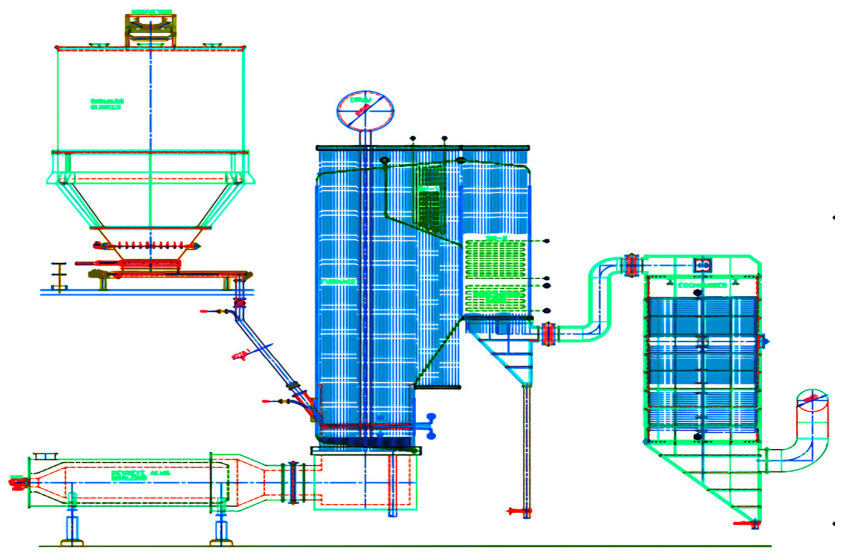

Fig. 1. Prototype plant \& fluid boiler-burner unit.

samples obtained from these mixtures were employed. For the tests conducted in different temperatures, biomass ash was heated in the ash furnace to the desired temperature. Weights and temperatures of the ashes used in the mixtures and codes of the mixtures are exhibited in Table 1.

Dry matter ratios of concocted samples were measured after weighing when dried at a temperature of $105^{\circ} \mathrm{C}$ to reach a fixed weight. To measure moisture content, the loss in total weight as samples arrived for the constant weighing process was observed [19]. To measure the $\mathrm{pH}$ and electric conductivity (EC) of samples, the water suspension method was employed. In compliance with EU standards, the $\mathrm{pH}$ was concocted in a ratio of 1:5 and, in a material-pure water suspension, measured via glass electrode $\mathrm{pH}$ meter [9-20]. EC, on the other hand, was measured via an EC electrode by paying attention to the heat after filtering of the material-pure water suspension through a Buchner funnel embedded with a Whatman 42 filter paper installed via a pressure pump [21]. Total organic matter content was calculated as a \% based on the principle of burning furnace dried $\left(105^{\circ} \mathrm{C}\right)$ samples in $550^{\circ} \mathrm{C}$ for a period of $4 \mathrm{~h}$. In the detection of heavy metal levels, an ICP-OES gadget was used in the samples prepared by the method of wet composition [22]. The total nitrogen content of samples was detected after transforming the nitrogen within the components into ammonia with concentrated sulphuric acid via the Kjeldahl method, based on the principle of conservation of ammonia in the form of ammonium sulphate. The formula was exhibited in \% ratio (Total $\mathrm{N}=$ Total Kjeldahl nitrogen $=$ ammonia nitrogen + organic nitrogen). Organic carbon content of the samples employed in this research was meas-

Table 1. Ratios of Ash and Poultry Manure Used in Mixtures

\begin{tabular}{ccccc}
\hline Aplication codes & Temperatures $\left({ }^{\circ} \mathbf{C}\right)$ & Ash ratio (\%) & Amount of ash (g) & Poultry litter (g) \\
\hline $\mathrm{PA}_{11}, \mathrm{PA}_{12}, \mathrm{PA}_{13}, \mathrm{PA}_{14}$ & $100,150,200,250$ & 10 & 74.77 & 1,000 \\
$\mathrm{PA}_{21}, \mathrm{PA}_{22}, \mathrm{PA}_{23}, \mathrm{PA}_{24}$ & $100,150,200,250$ & 20 & 149.54 & 1,000 \\
$\mathrm{PA}_{31}, \mathrm{PA}_{32}, \mathrm{PA}_{33}, \mathrm{PA}_{34}$ & $100,150,200,250$ & 30 & 224.31 & 1,000 \\
$\mathrm{PA}_{41}, \mathrm{PA}_{42}, \mathrm{PA}_{43}, \mathrm{PA}_{44}$ & $100,150,200,250$ & 40 & 299.08 & 1,000 \\
$\mathrm{PA}_{51}, \mathrm{PA}_{52}, \mathrm{PA}_{53}, \mathrm{PA}_{54}$ & $100,150,200,250$ & 50 & 373.85 & 1,000 \\
\hline
\end{tabular}

${ }^{*} \mathrm{PA}$ : poultry litter and biomass ash mixture, subscripts denote varied temperature levels. 
ured using the Walkley-Black method. C:N ratio was computed via rationing organic carbon/total nitrogen. All analyses within the scope of this study were replicated in triplicate, and the results were provided as the average of the three replications in \pm standard deviation.

\section{Results and Discussion}

General characteristics of the poultry manure employed in this study were determined, and the obtained results are exhibited in Table 2. Based on the results, it is viable to argue that samples of poultry manure contained $25.23 \%$ moisture content, with a $76.92 \%$ ratio of organic matter. The total ratio of nitrogen was high (5.13\% dry matter), and after nitrogen, the highest mineral in its content was calcium $(4.96 \%$ DM). High nitrogen content is the key characteristic of poultry manure. High ratios of calcium are due to calcium rich containing feed components, such as marble powder that are added into the mixtures used as poultry feed.

The macro- and microelement content of poultry manure can vary with respect to the material widely used as base, length of breeding period, characteristics of the poultry house, and feed content of fowl. Based on these reasons, characteristics of the poultry manure used in this study were evaluated by comparison with the features of poultry manure gathered in relevant literature studies.

In literature studies, the value ranges of certain characteristics of any poultry manure are as follows: moisture content $19-30 \%$, organic matter content 46-92\%, $\mathrm{pH}$ 6.3-8.4, EC 6.3-12.6 dS/m, organic carbon 29-38\% DM, total nitrogen 2.6-5.3, C:N 6.4-11.8, phosphorus $0.6-3.9 \%$ DM, potassium $0.7-5.7 \%$ DM and calcium 0.8-6.1\% DM. Based on these value ranges, it can be suggested that all values of the employed poultry manure fall within these ranges [15, 23-26].

Table 2. Characteristics of the Poultry Manure Used in This Study

\begin{tabular}{lc}
\hline \multicolumn{1}{c}{ Properties } & Broiler poultry manure \\
\hline Dry Matter (\%) & $74.77 \pm 2.26$ \\
Moisture Content (\%) & $25.23 \pm 2.26$ \\
Organic Matter (\% DM) & $76.92 \pm 3.41$ \\
$\mathrm{pH}$ & $8.10 \pm 0.18$ \\
EC (dS/m) & $6.76 \pm 0.49$ \\
Total Organic Carbon (\% DM) & $34.93 \pm 2.12$ \\
Total Nitrogen (\% DM) & $5.13 \pm 0.42$ \\
C:N & $6.82 \pm 0.20$ \\
Phosphorus (\% DM) & $2.32 \pm 0.96$ \\
Potassium (\% DM) & $2.14 \pm 0.21$ \\
Calcium (\% DM) & $4.96 \pm 0.60$ \\
Magnesium (\% DM) & $0.62 \pm 0.01$ \\
Sodium (\% DM) & $1.28 \pm 0.10$ \\
Germination Index & $92 \pm 9.60$ \\
\hline
\end{tabular}

On the other hand, in order to determine the phytotoxicity level of the fresh poultry manure, the germination test was conducted. The germination index (GI) was found to be 92 . To ensure that soil-improving materials and materials to be used in the plant breeding environment are non-phytotoxic, it is required to reach GI values above 100 [27]. The GI of poultry manure was measured to be below this value, which indicates that fresh poultry manure could trigger the phytotoxicity of plants in its pure form.

Biomass ash used in this study was obtained by burning forest industry wastes and agricultural wastes, such as corn hay and nut shells, inside a prototype power plant with a fluid tank burner unit. Table 3 displays certain characteristics of the employed ash.

As the values in Table 3 are examined, it is evidenced that the biomass ash employed in this study exhibits basic character $(\mathrm{pH}=12.14)$. Additionally, due its integral mineral content, it has a high EC value (14.28) and is rich in plant macronutrients. With regard to plant macronutrients maximum values were measured in calcium $(32.82 \%)$ and potassium (5.83\%). The obtained results were in compliance with relevant studies in the literature [28]. In literature studies for the general composition of biomass ash, there has been a relative differentiation with respect to the burned biomass type. It has also been reported that there were traces of silicium $\left(\mathrm{SiO}_{2}\right)$, calcium $(\mathrm{CaO})$, potassium $\left(\mathrm{K}_{2} \mathrm{O}\right)$, phosphorus $\left(\mathrm{P}_{2} \mathrm{O}_{5}\right)$, magnesium $(\mathrm{MgO})$ and sodium $\left(\mathrm{Na}_{2} \mathrm{O}\right)$ [28]. Among these minerals, the most pervasive one in biomass ash was silicium. Yet, silicium has not been used as a plant nutrient in agricultural practices. On that account, in this study that focused on the usability of plant nutrients included in biomass ash, silicium was excluded from the scope.

Values that show the effects of varied temperature mixtures of biomass ash on organic matter, total organic carbon, C:N ratio, pH, EC and GI are exhibited in Table 4. As the biomass ash ratio and temperature values of the mixtures increased, their organic matter and total organic carbon amounts decreased. Maximum organic matter $(74.46 \%)$ and total organic carbon content $(32.84 \%)$ were observed in the application where $10 \%$ biomass was harnessed in $100^{\circ} \mathrm{C}$, while minimum organic matter $(33.68 \%)$ and total organic carbon $(17.07 \%)$ values were observed in the application with maximum temperature level and ash ratio at $250^{\circ} \mathrm{C}$ with the infusion of $50 \%$ biomass ash. In applications

Table 3. Characteristics of Biomass Ash Employed in This Study

\begin{tabular}{lc}
\hline \multicolumn{1}{c}{ Properties } & Biomass ash \\
\hline $\mathrm{pH}$ & $12.14 \pm 0.90$ \\
$\mathrm{EC}(\mathrm{dS} / \mathrm{m})$ & $14.28 \pm 1.62$ \\
Phosphorus (\%) & $1.46 \pm 0.82$ \\
Potassium (\%) & $5.83 \pm 0.92$ \\
Calcium (\%) & $32.82 \pm 2.41$ \\
Magnesium (\%) & $5.34 \pm 0.80$ \\
Sodium (\%) & $0.96 \pm 0.09$ \\
Germination Index & $108 \pm 9.46$
\end{tabular}


Table 4. Some Chemical Properties of Biomass Ash and Poultry Manure Mixtures in Varied Ratios and Temperatures

\begin{tabular}{|c|c|c|c|c|c|c|}
\hline Applications & Organic matter (\%) & Total Organic Carbon (\%) & $\mathrm{C} / \mathrm{N}$ & $\mathrm{pH}$ & EC $(d S / m)$ & GI \\
\hline $\mathrm{PA}_{11}$ & $74.46 \pm 1.44$ & $32.84 \pm 4.26$ & $6.81 \pm 0.04$ & $8.2 \pm 0.20$ & $7.41 \pm 0.02$ & $102 \pm 3.73$ \\
\hline $\mathrm{PA}_{12}$ & $73.92 \pm 2.63$ & $32.16 \pm 3.16$ & $7.16 \pm 0.04$ & $8.2 \pm 0.30$ & $7.68 \pm 0.03$ & $103 \pm 7.34$ \\
\hline $\mathrm{PA}_{13}$ & $71.03 \pm 3.47$ & $30.61 \pm 3.85$ & $7.13 \pm 0.02$ & $8.2 \pm 0.13$ & $7.82 \pm 0.03$ & $107 \pm 2.10$ \\
\hline $\mathrm{PA}_{14}$ & $70.27 \pm 2.27$ & $29.67 \pm 3.44$ & $7.68 \pm 0.03$ & $8.2 \pm 0.43$ & $7.93 \pm 0.05$ & $108 \pm 5.20$ \\
\hline $\mathrm{PA}_{21}$ & $68.82 \pm 4.26$ & $30.12 \pm 3.11$ & $7.25 \pm 0.05$ & $8.4 \pm 0.36$ & $8.25 \pm 0.01$ & $106 \pm 6.43$ \\
\hline $\mathrm{PA}_{22}$ & $65.94 \pm 4.28$ & $28.76 \pm 3.62$ & $7.06 \pm 0.03$ & $8.4 \pm 0.33$ & $8.87 \pm 0.04$ & $107 \pm 4.13$ \\
\hline $\mathrm{PA}_{23}$ & $64.46 \pm 3.50$ & $26.46 \pm 2.60$ & $7.03 \pm 0.02$ & $8.3 \pm 0.23$ & $8.99 \pm 0.02$ & $110 \pm 1.76$ \\
\hline $\mathrm{PA}_{24}$ & $63.69 \pm 4.36$ & $25.94 \pm 3.75$ & $8.26 \pm 0.08$ & $8.3 \pm 0.30$ & $9.11 \pm 0.04$ & $116 \pm 1.10$ \\
\hline $\mathrm{PA}_{31}$ & $59.14 \pm 3.18$ & $27.54 \pm 4.11$ & $7.11 \pm 0.04$ & $8.7 \pm 0.36$ & $8.96 \pm 0.01$ & $118 \pm 8.74$ \\
\hline $\mathrm{PA}_{32}$ & $58.31 \pm 3.91$ & $27.09 \pm 2.97$ & $7.26 \pm 0.03$ & $8.6 \pm 0.33$ & $9.26 \pm 0.04$ & $121 \pm 2.80$ \\
\hline $\mathrm{PA}_{33}$ & $56.75 \pm 8.02$ & $24.32 \pm 3.07$ & $7.28 \pm 0.21$ & $8.6 \pm 0.40$ & $9.43 \pm 0.02$ & $124 \pm 0.50$ \\
\hline $\mathrm{PA}_{34}$ & $54.12 \pm 3.36$ & $23.77 \pm 4.50$ & $8.70 \pm 0.02$ & $8.5 \pm 0.23$ & $9.86 \pm 0.08$ & $129 \pm 3.73$ \\
\hline $\mathrm{PA}_{41}$ & $47.39 \pm 4.79$ & $25.39 \pm 4.15$ & $6.89 \pm 0.01$ & $9.0 \pm 0.30$ & $9.68 \pm 0.01$ & $125 \pm 0.16$ \\
\hline $\mathrm{PA}_{42}$ & $46.98 \pm 4.39$ & $24.92 \pm 5.74$ & $6.90 \pm 0.01$ & $8.9 \pm 0.40$ & $9.93 \pm 0.01$ & $133 \pm 4.36$ \\
\hline $\mathrm{PA}_{43}$ & $46.09 \pm 3.31$ & $21.68 \pm 3.02$ & $7.88 \pm 0.06$ & $8.9 \pm 0.33$ & $10.19 \pm 0.03$ & $139 \pm 2.30$ \\
\hline $\mathrm{PA}_{44}$ & $44.92 \pm 5.69$ & $20.10 \pm 2.01$ & $8.20 \pm 0.52$ & $8.8 \pm 0.26$ & $10.29 \pm 0.01$ & $146 \pm 2.30$ \\
\hline $\mathrm{PA}_{51}$ & $38.15 \pm 3.25$ & $21.53 \pm 2.78$ & $6.11 \pm 0.04$ & $9.3 \pm 0.20$ & $10.48 \pm 0.01$ & $138 \pm 3.70$ \\
\hline $\mathrm{PA}_{52}$ & $37.09 \pm 4.87$ & $19.80 \pm 3.28$ & $5.68 \pm 0.05$ & $9.3 \pm 0.30$ & $10.42 \pm 0.02$ & $142 \pm 1.13$ \\
\hline $\mathrm{PA}_{53}$ & $35.52 \pm 4.51$ & $17.83 \pm 3.25$ & $7.39 \pm 0.07$ & $9.1 \pm 0.36$ & $10.86 \pm 0.03$ & $151 \pm 4.50$ \\
\hline $\mathrm{PA}_{54}$ & $33.68 \pm 5.05$ & $17.07 \pm 1.28$ & $8.09 \pm 0.08$ & $9.1 \pm 0.23$ & $10.92 \pm 0.01$ & $158 \pm 4.10$ \\
\hline ANOVA & $* * *$ & $* * *$ & $* * *$ & $* * *$ & $* * *$ & $* * *$ \\
\hline
\end{tabular}

with the identical ash ratios, the rise in temperature led to a fall in total organic matter and organic carbon values. Since an acceleration of temperature and ash ratios in mixtures lowered nitrogen and organic carbon levels, this has also affected its $\mathrm{C}: \mathrm{N}$ ratio. However, there was a decrease in the $\mathrm{C}: \mathrm{N}$ ratio in $100^{\circ} \mathrm{C}$ and $150^{\circ} \mathrm{C}$ applications, while an increase of the $\mathrm{C}: \mathrm{N}$ ratio was observed in $200^{\circ} \mathrm{C}$ and $250^{\circ} \mathrm{C}$ applications. This was linked to the effect that an increase in temperature caused a greater loss of nitrogen in the mixture compared to the loss of carbon.

The $\mathrm{pH}$ value of the pure broiler poultry manure was measured as 8.1, and its EC value was $6.76 \mathrm{dS} / \mathrm{m}$. The $\mathrm{pH}$ (12.14) and EC $(14.28 \mathrm{dS} / \mathrm{m})$ values of biomass ash were higher than poultry manure values. Due to this discrepancy between $\mathrm{pH}$ and EC values of poultry manure and biomass ash, an increase in the biomass ash ratio applied in tests triggered a corresponding rise in the $\mathrm{pH}$ and $\mathrm{EC}$ values of mixtures. In the applications, maximum $\mathrm{pH}$ and EC values were measured as 9.3 and $10.92 \mathrm{dS} / \mathrm{m}$, respectively. An increase in the biomass ash temperature lowered its $\mathrm{pH}$ values but increased its EC values. On the other hand, a number of relevant literature studies indicated that $\mathrm{pH}$ was a salient parameter with regards to nitrogen loss, and a rapid rise in $\mathrm{pH}$ level accelerated some nitrogen loss. For instance, it has been reported that once an instant jump from $\mathrm{pH} 7$ to pH 8 has occurred, there has already been exponential nitrogen loss [29, 30]. Besides, the addition of hot biomass ash elevated the GI of poultry manure. The GI measured as 92 in unmixed poultry manure and increased as the employed ratio and temperature of biomass ash became higher. In the application conducted under $250^{\circ} \mathrm{C}$ with $50 \%$ biomass ash, a GI maximum value of 158 was reached.

\subsection{Lowering Poultry Manure Moisture Content by Applying Hot Biomass Ash}

Poultry manure enjoys huge potential thanks to the conserved plant nutrients. On the other hand, because of the adverse effects of poultry manure such as malodour and vector attraction, the emerging problems related to its storing and application are critical impediments in utilising such great potential.

The most effective and practical solution in the mitigation of these problems is lowering the moisture content of poultry manure. In this paper, waste heat of the biomass ashes was exhausted from biomass plants under a high temperature (around $400^{\circ} \mathrm{C}$ ) and were required to be cooled down before disposal processes were utilised in the drying procedure of poultry manure. The changes witnessed in manure moisture content through mixing varied ratios of biomass ashes and temperatures with the poultry manure have been displayed in Fig. 2. 


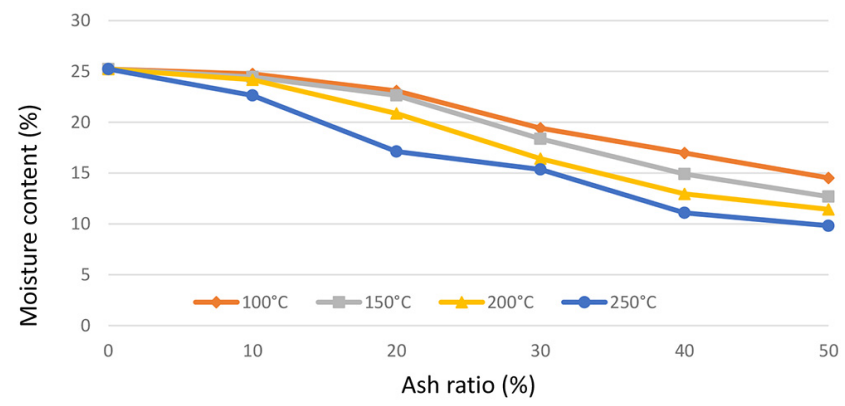

Fig. 2. Effects of varied ratios and temperatures of biomass ash on poultry manure moisture content.

The initial moisture content of raw poultry manure was measured as $25.23 \%$. As seen in Fig. 2, as the ratio and temperature of ash climbed, the moisture content of the mixtures decreased. The minimum moisture content $(9.82 \%)$ was observed in the $\mathrm{PA}_{54}$ application $\left(250^{\circ} \mathrm{C}\right.$ and $50 \%$ ash), in which the maximum temperature and ratio of ash was used. The maximum moisture value $(24.75 \%)$ was identified in the $\mathrm{PA}_{11}$ application $\left(100^{\circ} \mathrm{C}\right.$ and $10 \%$ ash) that used the minimum temperature and ash ratio. Once we analysed a sum of all the results obtained from these applications, it could be reasonably argued that hot biomass ash plays crucial role in lowering the moisture content of poultry manure.

\subsection{Effects of Biomass Ash on Plant Nutrients}

Variations of poultry waste piles on the concentration of total nitrogen are basically equal to organic nitrogen. Inorganic nitrogen concentrations are low, and organic nitrogen is the primary concentration with nitrogen [7]. In Fig. 3, the effects of mixing the hot biomass ash in this study with varied ratios of poultry manure on the ratio of poultry manure total nitrogen have been displayed. In both applications that employed biomass ash in $100^{\circ} \mathrm{C}$ and $150^{\circ} \mathrm{C}$ temperatures, identical results have been obtained. A rise in the ash ratio within mixtures led to a decrease in their nitrogen ratio. In this study, the level of decrease was quite similar in both applications.

This effect is linked to the fact that the cause of the nitrogen decrease was, rather than the temperature, the rise in ash ratio that triggered an increase in the mixture's solid matter ratio

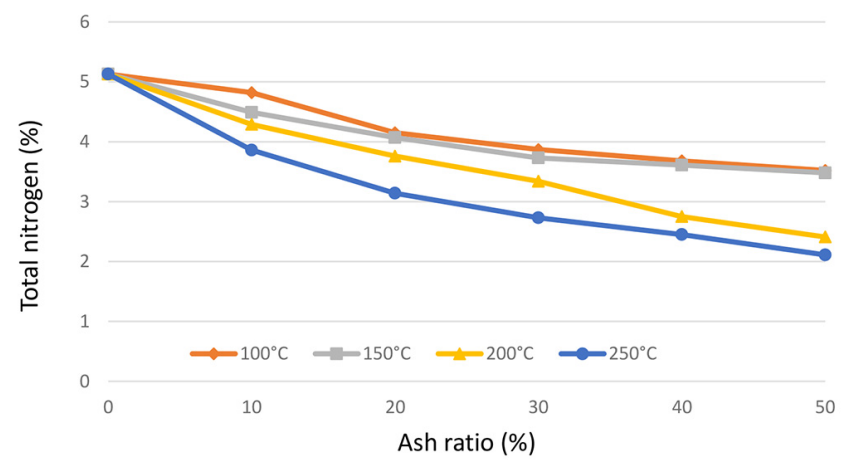

Fig. 3. Effects of varied ratios and temperatures of biomass ash on poultry manure total nitrogen $(\mathrm{N})$ ratio. and a decrease in the percentage ratio of nitrogen solid matter, or its dilution to say it differently. The initial nitrogen ratio of poultry manure was $5.13 \%$. The minimum nitrogen ratios detected in $100^{\circ} \mathrm{C}$ and $150^{\circ} \mathrm{C}$ temperatures have been measured in the $\mathrm{PA}_{14}(3.52 \%)$ and $\mathrm{PA}_{24}(3.48 \%)$ applications that utilise the maximum ash ratio.

However, in applications that used biomass ashes in $200^{\circ} \mathrm{C}$ and $250^{\circ} \mathrm{C}$ temperatures, a higher level of nitrogen loss was measured. The nitrogen ratio of the $\mathrm{PA}_{43}$ application that used $50 \%$ biomass ash in $200^{\circ} \mathrm{C}$ was found to be $2.41 \%$, while in the $\mathrm{PA}_{54}$ application that used $50 \%$ biomass ash in $250^{\circ} \mathrm{C}$, the nitrogen ratio was measured as $2.11 \%$. This has been the application in which the minimum nitrogen ratio was measured. In the applications with $200^{\circ} \mathrm{C}$ and $250^{\circ} \mathrm{C}$ temperature levels, the decrease in the nitrogen ratio was due to the increase in temperature rather than the increase in biomass ash ratio.

In relevant literature studies on nitrogen loss, it surfaced that nitrogen loss varied with respect to ventilation, moisture content, $\mathrm{pH}$, age of manure and temperature [7-30]. Similar studies have also reported that drying high poultry manure under high temperatures led to some nitrogen loss. Sommer and Olsen detected that in the fast drying process performed under high temperatures, a linear correlation emerged between the rapid temperature increase and drying process with nitrogen loss [8].

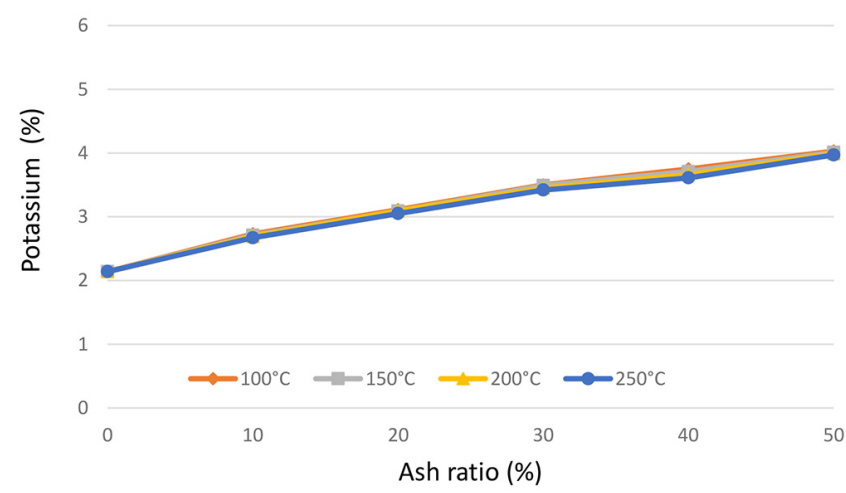

Fig. 4. Effects of varied ratios and temperatures of biomass ash on poultry manure potassium $(\mathrm{K})$ ratio.

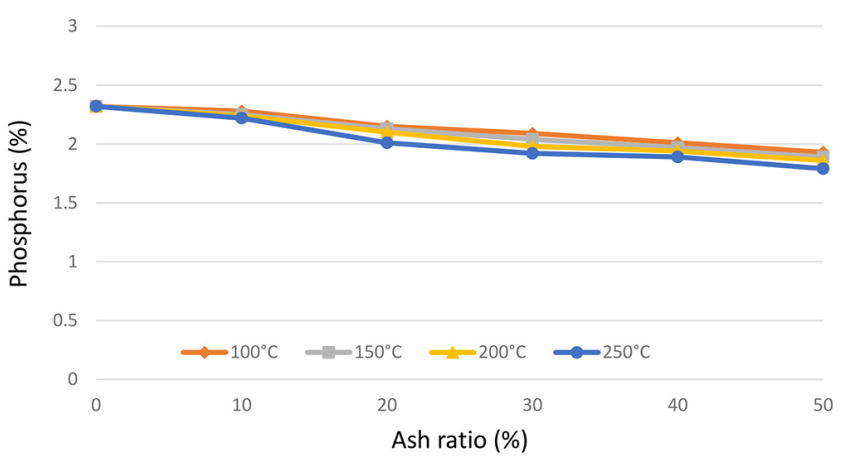

Fig. 5. Effects of varied ratios and temperatures of biomass ash on poultry manure phosphorus $(\mathrm{P})$ ratio. 
Table 5. Micro Nutrients and Heavy Metal Content of Biomass Ash and Poultry Manure Mixtures in Varied Ratios and Temperatures

\begin{tabular}{|c|c|c|c|c|c|c|c|c|c|}
\hline Applications & $\begin{array}{c}\mathrm{Zn} \\
(\mathrm{mg} / \mathrm{kg})\end{array}$ & $\begin{array}{c}\mathrm{Cu} \\
(\mathrm{mg} / \mathrm{kg})\end{array}$ & $\begin{array}{c}\mathrm{Ni} \\
(\mathrm{mg} / \mathrm{kg})\end{array}$ & $\begin{array}{c}\mathrm{Pb} \\
(\mathrm{mg} / \mathrm{kg})\end{array}$ & $\begin{array}{c}\mathrm{Cr} \\
(\mathrm{mg} / \mathrm{kg})\end{array}$ & $\begin{array}{c}\text { Cd } \\
\text { (mg/kg) }\end{array}$ & $\begin{array}{c}\text { Fe } \\
(\mathrm{mg} / \mathrm{kg})\end{array}$ & $\begin{array}{c}\mathrm{Mn} \\
(\mathrm{mg} / \mathrm{kg})\end{array}$ & $\begin{array}{c}\text { Co } \\
\text { (mg/kg) }\end{array}$ \\
\hline $\mathrm{P}$ & $\begin{array}{c}361.09 \pm \\
2.91\end{array}$ & $\begin{array}{c}60.34 \pm \\
1.13\end{array}$ & $\begin{array}{c}12.4 \pm \\
2.28\end{array}$ & $\begin{array}{c}10.21 \pm \\
2.21\end{array}$ & $\begin{array}{c}9.58 \pm \\
1.40\end{array}$ & $\begin{array}{c}1.4 \pm \\
0.36\end{array}$ & $\begin{array}{c}752.14 \pm \\
7.73\end{array}$ & $\begin{array}{c}321.14 \pm \\
5.62\end{array}$ & $\begin{array}{c}0.35 \pm \\
0.04\end{array}$ \\
\hline A & $\begin{array}{c}657.64 \pm \\
4.93\end{array}$ & $\begin{array}{c}45.93 \pm \\
2.75\end{array}$ & $\begin{array}{c}25.34 \pm \\
4.19\end{array}$ & $\begin{array}{c}28.36 \pm \\
3.59\end{array}$ & $\begin{array}{c}47.68 \pm \\
3.92\end{array}$ & $\begin{array}{c}2.18 \pm \\
0.27\end{array}$ & $\begin{array}{c}1,843.72 \pm \\
9.95\end{array}$ & $\begin{array}{c}1,013.56 \pm \\
6.68\end{array}$ & $\begin{array}{c}4.28 \pm \\
0.48\end{array}$ \\
\hline $\mathrm{PA}_{1}$ & $\begin{array}{c}376.78 \pm \\
4.64\end{array}$ & $\begin{array}{c}58.99 \pm \\
4.57\end{array}$ & $\begin{array}{c}13.93 \pm \\
3.46\end{array}$ & $\begin{array}{c}13.33 \pm \\
1.93\end{array}$ & $\begin{array}{c}11.70 \pm \\
1.86\end{array}$ & $\begin{array}{c}1.26 \pm \\
0.17\end{array}$ & $\begin{array}{c}767.46 \pm \\
9.12\end{array}$ & $\begin{array}{c}436.15 \pm \\
4.07\end{array}$ & $\begin{array}{c}0.99 \pm \\
0.20\end{array}$ \\
\hline $\mathrm{PA}_{2}$ & $\begin{array}{c}401.24 \pm \\
2.41\end{array}$ & $\begin{array}{c}57.89 \pm \\
4.92\end{array}$ & $\begin{array}{c}15.13 \pm \\
1.36\end{array}$ & $\begin{array}{c}14.53 \pm \\
1.74\end{array}$ & $\begin{array}{c}17.19 \pm \\
2.30\end{array}$ & $\begin{array}{c}1.42 \pm \\
0.18\end{array}$ & $\begin{array}{c}834.27 \pm \\
6.85\end{array}$ & $\begin{array}{c}481.94 \pm \\
9.57\end{array}$ & $\begin{array}{c}1.39 \pm \\
0.18\end{array}$ \\
\hline $\mathrm{PA}_{3}$ & $\begin{array}{c}424.35 \pm \\
4.28\end{array}$ & $\begin{array}{c}54.42 \pm \\
3.94\end{array}$ & $\begin{array}{c}16.26 \pm \\
2.15\end{array}$ & $\begin{array}{c}16.38 \pm \\
2.92\end{array}$ & $\begin{array}{c}29.43 \pm \\
1.68\end{array}$ & $\begin{array}{c}1.52 \pm \\
0.20\end{array}$ & $\begin{array}{c}1,013.45 \pm \\
7.22\end{array}$ & $\begin{array}{c}572.16 \pm \\
17.62\end{array}$ & $\begin{array}{c}2.57 \pm \\
0.22\end{array}$ \\
\hline $\mathrm{PA}_{4}$ & $\begin{array}{c}435.16 \pm \\
5.56\end{array}$ & $\begin{array}{c}50.15 \pm \\
2.64\end{array}$ & $\begin{array}{c}19.2 \pm \\
4.01\end{array}$ & $\begin{array}{c}18.21 \pm \\
2.49\end{array}$ & $\begin{array}{c}38.74 \pm \\
2.93\end{array}$ & $\begin{array}{c}1.61 \pm \\
0.27\end{array}$ & $\begin{array}{c}1,262.16 \pm \\
13.49\end{array}$ & $\begin{array}{c}768.14 \pm \\
14.83\end{array}$ & $\begin{array}{c}3.01 \pm \\
0.17\end{array}$ \\
\hline $\mathrm{PA}_{5}$ & $\begin{array}{c}479.96 \pm \\
6.14\end{array}$ & $\begin{array}{c}47.99 \pm \\
3.33\end{array}$ & $\begin{array}{c}21.81 \pm \\
2.83\end{array}$ & $\begin{array}{c}21.96 \pm \\
1.86\end{array}$ & $\begin{array}{c}44.49 \pm \\
5.35\end{array}$ & $\begin{array}{c}1.89 \pm \\
0.29\end{array}$ & $\begin{array}{c}1,545.63 \pm \\
9.55\end{array}$ & $\begin{array}{c}812.61 \pm \\
7.01\end{array}$ & $\begin{array}{c}3.12 \pm \\
0.28\end{array}$ \\
\hline ANOVA & $* * *$ & $* * *$ & ** & $* * *$ & $* * *$ & ** & $* * *$ & $* * *$ & $* * *$ \\
\hline
\end{tabular}

The potassium ratio of the biomass ash used in this study was measured as $5.83 \% \mathrm{DM}$, and this value is twice more than the potassium content of poultry manure $(2.14 \% \mathrm{DM})$. Thereby, as biomass ash ratio of the mixtures increased, the potassium content of the mixtures also increased. The maximum potassium content was obtained in the $\mathrm{PA}_{14}$ application that applied $50 \%$ biomass ash in $250^{\circ} \mathrm{C}$.

As the effects of hot biomass ash on poultry manure phosphorus (P) content are examined, it is feasible to argue that the temperature of the ash plays an insignificant role on phosphorus content. On the other hand, the phosphorus ratio of $(2.32 \%$ $\mathrm{DM})$ pure poultry manure is higher than the biomass ash $(1.46 \%$ DM). Thus, as the ash ratio of mixtures increased, the phosphorus content of poultry manure decreased. In the applications in this study, the minimum phosphorus value was $1.79 \% \mathrm{DM}$, which was measured in the PA54 application that used 50\% biomass ash in $250^{\circ} \mathrm{C}$.

\subsection{Effects of Biomass Ash Application on Poultry Manure Microelement Content}

It has been determined that applied biomass ash enriched poultry manure in all of the analysed plant micronutrients. The maximum increments in the poultry manure plant micronutrients were observed in iron (Fe), manganese ( $\mathrm{Mn})$ and zinc $(\mathrm{Zn})$. The iron, manganese and zinc maximum values were observed in the application that used the highest biomass ash (50\%), which were identified 1,545.65 mg/kg, $812.61 \mathrm{mg} / \mathrm{kg}$ and $479.96 \mathrm{mg} / \mathrm{kg}$, respectively. Other microelements such as copper $(\mathrm{Cu})$, nickel $(\mathrm{Ni})$, lead $(\mathrm{Pb})$, chrome $(\mathrm{Cr})$, cadmium $(\mathrm{Cd})$ and cobalt (Co) provided maximum values that were $47.99 \mathrm{mg} / \mathrm{kg}, 21.81 \mathrm{mg} / \mathrm{kg}$, $21.96 \mathrm{mg} / \mathrm{kg}, 44.49 \mathrm{mg} / \mathrm{kg}, 1.89 \mathrm{mg} / \mathrm{kg}$ and $3.12 \mathrm{mg} / \mathrm{kg}$, respectively (Table 5).

\section{Conclusions}

The main objective of this study was to offer a cost-effective, ecological and sustainable method of disposal for poultry manure and biomass ash and revealed that an increase in ash ratio and temperature level led to a significant decrease in the moisture content of poultry manure. In the application that utilised biomass ash at maximum ratio and temperature (50\% biomass ash in $250^{\circ} \mathrm{C}$ ), the moisture content of poultry manure decreased to $9.82 \%$. Considering that the moisture inside poultry manure is the primary cause of malodour and fast dissolution, it becomes evident that such a decrease in moisture content would provide major benefits in the alleviation of adverse characteristics of poultry manure. Furthermore, with the addition of biomass ash, poultry manure became incredibly rich in plant macro- and micronutrients. Biomass ash contains high ratios of $\mathrm{Ca}, \mathrm{K}, \mathrm{Fe}$, $\mathrm{Mn}$ and $\mathrm{Zn}$. In the application that used maximum biomass ash (50\%), Ca 19.34\%, K 4.03\%, Fe 1,545.63 mg/kg, Mn 812.61 $\mathrm{mg} / \mathrm{kg}$ and $\mathrm{Zn} 479.96 \mathrm{mg} / \mathrm{kg}$ content was achieved. Temperature variations had no significant effect on plant macro- and micronutrient content, except nitrogen. It has also been concluded that biomass ash is one of the most effective potassium sources and mixing it with pure as well as organic-based manure, such as poultry manure, could meet potassium requirements in plant-based production. Thereby, leading to a potential decrease in the demand for chemical fertiliser.

\section{References}

1. Shan L, He Y, Chen J, Huang Q, Wang H. Ammonia volatilization a Chinese cabbage field under different nitrogen treatments in the Taihu Lake Basin, China. J. Environ. Sci. 
2015;38:14-23.

2. Haynes RJ, Naidu R. Influence of lime, fertilizer and manure applications on soil organic matter content and soil physical conditions: A review. Nutr. Cycl. Agroecosyst. 1998;51:123-137.

3. Liu E, Yan C, Mei X, et al. Long-term effect of chemical fertilizer, straw, and manure on soil chemical and biological properties in northwest China. Geoderma 2010;158:173-180.

4. Kominko H, Gorazda K, Wzorek Z. The possibility of organo-mineral fertilizer production from sewage sludge. Waste Biomass Valor. 2017;8:1781-1791.

5. Florio A, Felici B, Miglione M, Dell'Abate MT, Benedetti A. Nitrogen losses, uptake and abundance of ammonia oxidizers in soil under mineral and organo-mineral fertilization regimes. J. Sci. Food Agr. 2016;96:2440-2450.

6. Preusch PL, Adler PR, Sikora LJ, Tworkoski TJ. Nitrogen and phosphorus availability in composted and uncomposted poultry litter. J. Environ. Qual. 2002;31:2051-2057.

7. Tiquia SM, Tam NFY. Fate of nitrogen during composting of chicken litter. Environ. Pollut. 2000;110:535-541.

8. Sommer SG. Effect of composting on nutrient loss and nitrogen availability of cattle deep litter. Eur. J. Agron. 2001;14: 123-133.

9. Benito M, Masaguer A, Moliner A, De Antonıor R. Chemical and physical properties of pruning waste compost and their seasonal variability. Bioresour. Technol. 2006;97:2071-2076.

10. Ogunwande GA, Osunade JA, Adekalu KO, Ogunjimi LAO. Nitrogen loss in chicken litter compost as affected by carbon to nitrogen ratio and turning frequency. Bioresour. Technol. 2008;99:7495-7503.

11. Erisman JW, Bleeker A, Galloway J, Sutton MS. Reduced nitrogen in ecology and the environment. Environ. Pollut. 2007;150:140-149.

12. Oenema O, Witzke HP, Klimont Z, Lesschen JP, Velthof GL. Integrated assessment of promising measures to decrease nitrogen losses from agriculture in EU-27. Agr. Ecosyst. Environ. 2009;133:280-288.

13. Sims JT, Wolf DC. Poultry waste management: Agricultural and environmental issues. Adv. Agron. 1994;52:1-83.

14. Wood CW, Hall BM. Impact of drying method on broiler litter analyses. Commun. Soil Sci. Plant Anal. 1991;22:1677-1688.

15. Lopez-Mosquera ME, Cabaleiro F, Sainz MJ, Lopez-Fabal A, Carral E. Fertilizing value of broiler litter: Effects of drying and pelletizing. Bioresour. Technol. 2008;99:5626-5633.

16. Vassilev SV, Baxter D, Andersen LK, Vassileva CG. An overview of the chemical composition of biomass. Fuel 2010;89:
913-933.

17. Baxter XC, Darvell LI, Jones JM, Barraclough T, Yates NE, Shield I. Miscanthus combustion properties and variations with miscanthus agronomy. Fuel 2014;117:851-869.

18. Khan MR, Khan MW. The effect of fly ash on plant growth and yield of tomato. Environ. Pollut. 1996;92:106-111.

19. Alvarez R, Liden G. Low temperature anaerobic digestion of mixtures of llama, cow and sheep manure for improved methane production. Biomass Bioenerg. 2009;33:527-533.

20. Ozdemir S, Dede OH, Koseoglu G. Recycling of MSW compost and sewage sludge as growing substrate for ornamental potted plants. Fresen. Environ. Bull. 2004;13:30-33.

21. Abad M, Noguera P, Puchades R, Maquieira A, Noguera V. Physico-chemical and chemical properties of some coconut coir dusts for use as a peat substitute for containerised ornamental plants. Bioresour. Technol. 2003;82:241-245.

22. Eliche-Quesada D, Leite-Costa J. Use of bottom ash from olive pomace combustion in the production of eco-friendly fired clay bricks. Waste Manage. 2016;48:323-333.

23. Brown JE, Gilliam CH, Shumack RL, Porch DW. Commercial snap bean response to fertilization with broiler litter. HortScience 1993;28:29-31.

24. Cummins CG, Wood CW, Delaney DP. Co-composted poultry mortalities and poultry litter: Composition and potential value as a fertilizer. J. Sustain. Agr. 1994;4:7-19.

25. Ekinci K, Keener HM, Elwell DL. Composting short paper fiber with broiler litter and additives. Part I: Effects of initial $\mathrm{pH}$ and carbon/nitrogen ratio on ammonia emission. Compost Sci. Util. 2000;8:160-172.

26. Flynn PR, Wood CW. Temperature and chemical changes during composting of broiler litter. Compost Sci. Util. 1996;4:62-70.

27. Lau SSS, Wong JWC. Toxicity evaluation of weathered coal fly ash-amended manure compost. Water Air Soil Pollut. 2001;128:243-254.

28. Chen C, Zhangc P, Zenga G, Denga J, Zhoua Y, Lud H. Sewage sludge conditioning with coal fly ash modified by sulfuric acid. Chem. Eng. J. 2010;158:616-622.

29. Carr LE, Wheaton FW, Douglass LW. Empirical models to determine ammonia concentrations from broiler chicken litter. Trans. ASAE 1990;33:1337-1342.

30. Choi IH, Moore PA. Effect of various litter amendments on ammonia volatilization and nitrogen content of poultry litter. J. Appl. Poultry Res. 2008;17:454-462. 